Article

\title{
Ecological Criteria for Comparing Linear and Circular Economies
}

\author{
Nikolay I. Didenko * (D), Yuri S. Klochkov (iD) and Djamilia F. Skripnuk (ii) \\ Peter the Great St. Petersburg Polytechnic University, St. Petersburg 195251, Russia; y.kloch@gmail.com (Y.S.K.); \\ djamilyas@mail.ru (D.F.S.) \\ * Correspondence: didenko.nikolay@mail.ru; Tel.: +7-911-280-96-09
}

Received: 28 June 2018; Accepted: 4 August 2018; Published: 8 August 2018

\begin{abstract}
In the present article, the main principles of the circular economy are outlined in contradistinction with the existing and traditional linear economic model. An econometric model describing the influence of the linear economy on the environment is presented. The environment is characterized by seven key processes: change in global temperature; emissions of greenhouse gases from industry to the environment; emissions of greenhouse gases from agriculture to the environment; $\mathrm{CO}_{2}$ emissions into the environment; depletion of fresh water supplies; reduction of forest cover; and economic damage from climatological disasters. The model describing the impact of the traditional linear economy on the environment consists of seven interdependent econometric equations, each comprising an autoregressive distributed lag (ADL)-model. The proposed econometric model is used to analyze the environmental effects of the present linear economy. Methodological provisions for a transformational transition of the traditional linear economic model to the closed-loop systems, which also permit the impact of the closed-loop systems on the environment to be analyzed, are set out. Seven ecological indicators are proposed as criteria for comparing the traditional linear economy and the closed-loop systems. The manuscript presents a new approach for the determination of ecological criteria for comparing linear and circular economies. The results of the study could be interesting to address circular processes, which can be used as a criterion to establish ecological management according to the status of natural resources.
\end{abstract}

Keywords: circular economy; linear economy; environment; influence of the linear economy on the environment; ADL-model

\section{Introduction}

In recent years, references to a circular economic model (closed-loop systems) are increasingly encountered as an alternative to the traditional linear economic model. The basic principles of the circular economic model (closed-loop systems) are based on maximizing the value of the resources in use, the reuse of production and consumption wastes, and transition to the use of renewable energy sources. In comparison with the currently dominant model, the circular economy presupposes a different system of human interaction in the spheres of production and consumption and eradicates waste through careful design. The methodology of the circular economy is based on the understanding that all thoughts and actions of the manufacturer of a product at the stage of manufacture should be aimed at understanding what to do with the product once its service life is complete. In other words, the production, consumption, and disposal of a product should not be associated with increased waste production. Rather, at the end of its life cycle, a product should be thought of as a resource rather than debris to be disposed of in landfill or by incineration. Even at the stage of originating the idea to create a new product, it is necessary to also generate ideas about the circulation of the product in the economic system in such a way that it minimizes waste at all stages of its life cycle. Thus, a 
materials-and-energy cycle is created within the economic system in accordance with the principles of the circular economy: recycle waste, reuse the components of old products, repair and improve components, and use a systematic approach that takes into account how the goods will circulate in the economic system.

According to the principles of the circular economy, recycling can be beneficial to the global economy by creating new jobs, saving resources, and preventing waste. At the same time, however, it remains entirely possible that the reprocessing, repair, modification, and reutilization processes associated with it can entail more energy and material costs than the production, use, and disposal of an end-of-life product. The circular economy is aimed at solving the problem of repeated use of production and consumption wastes by increasing the reuse of resources and reducing waste.

The difference between the linear and circular economies is most prominently shown in References [1,2].

Michelini et al. [1] note that the current linear socio-economic system is characterized by the destruction of the product at the end of its service life and that it is one of the main causes of severe depletion of natural resources. The circular economy is based on the principles of a new resource-efficient economic model as opposed to a linear one, and it is ultimately a restorative circular economy. The authors consider the Product-Service System (PSS) as the main business model for the linear economy at the micro-level, and they offer a mechanism for using the PSS as a business model for companies and closed-loop systems. Geissdoerfer et al. [2] believe that the main difference between the linear and circular economies is the representation of the circular economy as a more sustainable system that allows solving the problems of limited resources without compromising growth and prosperity. At its core, the circular economy is seen as a possible solution to the problem of sustainable development.

Here, depending on the concept of its development, the circular economic model (closed-loop systems) - in common with the traditional linear economy - can be characterized by the powerful anthropogenic impact of people on the environment. Excessive human interference in biospheric systems violates their balance and internal connections. These actions can lead to ecological catastrophe. The rapid development of human economic activity leads to intense and often destructive impacts on the environment. This leads to a sharp deterioration in the state of the natural environment, often with irreversible consequences.

There is a large number of works providing an analysis of environmental problems and possible approaches to their solution from the perspective of a linear economy shown in References [3-13]. Researchers analyzing data on industrial emissions of $\mathrm{CO}_{2}$ - the main greenhouse gas-have coalesced around the Global Carbon Project to study the main sources of atmospheric pollution, i.e., fuel and energy enterprises as well as manufacturing and transport industries. The empirical study of Grossman and Krueger [14] reveals an inverted U-shaped relationship_-also known as an Environmental Kuznets Curve (EKC) - between financial income and local air and water pollutants. Subsequent studies [15-17] have given rise to numerous empirical studies that measured and analyzed the relationship between the environment, the economy, and industrial policies. In addition to Grossman and Krueger [18], Khimeli and Braden [19] also consider models about the impact of large-scale industrial production on the environment. Lahiri [20] examines the impact of income factors and environmental quality on growth performance for open economies. This result differs from the standard result of convergence for identical economies. This asymmetric result is analyzed in terms of scale, composition, and intensity, which, as is known, underlie the environmental Kuznets curve relation. However, the empirical study by Miglietta et al. [21] reveals the relationship between economic growth and water consumption in the world as an N-shape curve that does not support the EKC hypothesis. Using linear and nonlinear models, the ratio between the impact of water and gross national income (GNI) per capita in 94 countries is estimated in the paper [21] by the usual least square. 
Stokey [22] explores how different production technologies affect environmental outcomes, while Stahl and Taisch [23] investigate how a company's choice of alternative energy resources affects the quality of the environment.

Reviews of the literature according to Carson [24], Didenko and Skripnuk [25], and Krasulina [26] indicate the need to construct structural theoretical models of the interrelation between industry and the environment as well as the need to construct a system of interdependent equations with a large number of endogenous variables. Yuri Izrael [27] argues that to reach an acceptable level by 2050, it will be necessary to reduce global $\mathrm{CO}_{2}$ emissions by $50-85 \%$, which is technically impossible. Methods for stabilizing the climate-in particular, the introduction of highly dispersed aerosol particles into the lower stratosphere-are proposed. Belay, Recha, Woldeamanuel, and Morton have investigated [28] how small farmers in Ethiopia perceive climate change, what adaptation strategies they practice as well as factors that influence their adaptation decisions.

Bekhet and Othman [29] study the links between urban growth and $\mathrm{CO}_{2}$ emissions in the context of Malaysia. The study of the relationship between $\mathrm{CO}_{2}$ emissions, growing urbanization, increased energy consumption, GDP, domestic investment, and financial development is also analyzed in Kumar et al. [30], where it is shown that urbanization is a constantly accelerating global phenomenon that requires the correct interaction between anthropogenic activities and the urban medium. Urbanization is seen in Sang and Bekhet [31] as a phenomenon of economic and social modernization. The relationship between urban growth and $\mathrm{CO}_{2}$ emissions for Malaysia is being studied with the aim of reducing pollution. The Cobb-Douglas production function is used to better understand the interaction between $\mathrm{CO}_{2}$ emissions and urbanization during the period 1971 to 2015. This study is aimed at exploring the relationship between $\mathrm{CO}_{2}$ emissions, urbanization growth, energy consumption, GDP, internal investments, and financial development. Dynamic relationships between variables and the long-term relationship between $\mathrm{CO}_{2}$ emissions and urbanization are considered.

Karl and Trenberth [32] present reports on the impact of human civilization on the Earth's climate, the importance of international efforts in long-term climate control, the role of computer climate modeling in predicting changes in the environment, and attempts to recreate climatic conditions prior to the Industrial Revolution. In the article by Bilgili et al. [33], the statistically significant influence of biomass energy consumption on $\mathrm{CO}_{2}$ and GDP emissions in the USA is analyzed. In the article by Waha et al. [34], the region of the Middle East and North Africa (MENA) serves as one of the territories for the analysis of deterioration of conditions, including extreme heat and drought in the face of climate change.

The short- and long-term effects of income inequality, economic growth, internal investment, trade openness, and energy consumption on carbon dioxide $\left(\mathrm{CO}_{2}\right)$ emissions in Malaysia, Indonesia, the Philippines, and Thailand were studied by Ridzuan et al. [35] using the autoregressive distributed lag (ADL) model. The annual data used in this study cover the period from 1971 to 2013. An environmental assessment of the various processes to improve the supply efficiency of food and products to the ever-growing population in the world is given by Maier and Shahzad [36]. The role of climate and industry in the formation of aquatic ecosystems is discussed in Summers et al. [37].

The livestock sector provides more than a third of human needs in terms of proteins and is the main source of livelihood in almost all developing countries. While providing such huge benefits to the population, the potentially adverse environmental impacts of poor livestock management at the local, regional, and national levels, which have not been duly eliminated in many emerging economies, is substantiated by Sakadevan and Nguyen [38]. Liu et al. [39] propose the leaf area index as a key parameter for characterizing the vegetation dynamics and ecosystem structure, defined in terms of functions and services such as clean water supply and carbon uptake at the watershed. In Reference [40], environmental descriptors are proposed as cost-effective biodiversity indicators, which are necessary for regional and global biodiversity monitoring. It is shown in Ellis et al. [41] that exponentially increasing $\mathrm{CO}_{2}$ leads to climate change and causes acidification of both marine and freshwater environments. 
In Liu et al. [42], the rapid development of China's social economy in terms of effective reforms and policies is analyzed based on thirty years of statistics. The development of society has led to a wider use of many natural resources to the extent that the ecosystem can no longer self-regulate, which seriously disrupts the balance of the ecosystem itself. This, in turn, has led to a deterioration in people's living conditions.

In Riti et al. [43], an examination of the consequences of energy use and financial development indicators by sources in the "environment-growth-energy" model is carried out on over 90 countries between 1980 and 2014. The results show that across all categories of countries, energy consumption and GDP per capita are the main drivers of $\mathrm{CO}_{2}$ emissions. On the other hand, renewable energy sources and financial development help to reduce $\mathrm{CO}_{2}$ emissions. Therefore, policy should be aimed at stimulating investment in renewable energy technologies.

In order to assess the possible impacts of climate change on the hydrological regime of the two large Lena and Mackenzie river basins, applied geophysics and hydrological forecasting models by Gelfan et al. [44] were developed. On the assumption that future environments will differ from existing ones, Millar et al. [45] propose a conceptual framework for ecosystem management that includes forests; however, the specifics of the changes remain unknown. Flexible approaches involving reversible and incremental steps are encouraged for continuous learning and the ability to change direction in changing situations have been demonstrated by Hinzman et al. [46]. They also examine how the Arctic climate is changing, permafrost is warming up, and hydrological processes are changing as well as discuss the development of biological and social systems in response to these changing conditions.

In the study by Wang et al. [47], a complex simulation model for assessing the risk associated with natural disasters and social emergencies is proposed. In this paper, a mechanism is introduced to reflect changes in the aquatic environment and understand natural processes relating to nonpoint sources of pollution in the Lake Dianchi basin. The livestock sector, which provides more than a third of human needs in terms of proteins and comprises the main source of livelihood in almost all developing countries, is described by Sakadevan and Nguyen [38], Pasiakos et al. [48]. Due to the significant benefits the livestock sector provides to the population, the potentially adverse environmental impacts of poor livestock management at the local, regional, and national levels have not been duly eliminated in many emerging economies. With $26 \%$ of the available land area used for animal husbandry worldwide, forest cover is constantly being lost to such activities. This sector, which contributes around $14.5 \%$ of all human-induced greenhouse gas emissions, is one of the largest sources of greenhouse gases; it also leads to the use and consequent contamination of freshwater and contributes to biodiversity loss. The allocation of around $60 \%$ of annually harvested global biomass to the livestock sector can be seen to undermine its sustainability. Despite the negative effects of livestock production, there are possibilities for balancing the competing needs of livestock and the environment.

Analysis of articles on problems of the circular economy shows the following: The articles contain definitions and business models of the circular economy for different objects-firms, industries, and territories. The general concept of circular economy management does not exist. In addition, there is no generally accepted system of concepts in the sphere of circular economy.

The principles of the circular economy are quite different in the developed and developing countries. We find an explanation of this fact in some articles. Using the example of plastic waste management in Kenya, Horvath, Mallinguh, and Fogarassy [49], show that business solutions—-defined for advanced economies-will not fully operate for the rest of the world. Ilić and Nikolić [50] state that poor waste management in developing countries indicates that waste generation is mostly associated with the economic status of a society and their weak socio-economic factors that are affected by the absence of proper environmental legislation, financial management, and administrative capacities. Saavedra et al. [51] have conducted a bibliometric literature review based on the core journals listed in China National Knowledge Infrastructure and Scopus and Web of Science databases with the Cite Space V over the period 2000-2016 as the background. Results show evident interactive feedback between public policy and academic research. The development of circular economy, as shown in 
the work [51], played a much more important role, as it promoted an important part of the ecological civilization and comprehensive construction of the well-off society in China. Fogarassy et al. [52] argue that in order to implement the principles of closed-loop systems, pilot projects are required as a first step to implement technological and business solutions.

In our opinion, governments of developing countries can more effectively use the technological and business solutions of closed-loop systems by organizing and financing pilot projects in various sectors of the national economy.

The circular economy (CE) is currently a popular concept promoted by the European Union (EU), several national governments, and many companies around the world. However, many researchers consider in references $[53,54]$ that at the conceptual level, the content of the CE concept looks rather superficial and scientifically unorganized. Korhonen, Honkasalo, and Seppälä [53] consider that there are a lot of publications on CE issues, but at the same time, "it seems that CE is a collection of vague and separate ideas from several fields and semi-scientific concepts". In addition, they question the unifying link of these different approaches to the definition of CE. Korhonen et al. [53], Kalmykova, Sadagopan, and Rosado [54] consider that using the CE concept will make progress in sustainable development of economic systems and ecological sustainable development. Currently, the process of elaborating the CE concept is taking place in Europe, which is reflected in the fact that most of the relevant literature is published in the form of documents on the scope and initiatives of governments and non-governmental organizations. We consider that the idea of sustainable development is, in fact, the supreme objective that cannot be solved within the linear economy and which continues to be addressed within the $\mathrm{CE}$ framework, both by theorists and practitioners.

Theoretical researchers study the CE from the position of the main definitions, boundaries of use, and conceptual provisions as set out in the references [55-61]. The main scientific publications of practical orientation shown in the references [2,62-64] relate to the development of business models for companies of various industries. Kirchherr, Reike, and Hekkert [55] define the CE as a closed-loop system that reduces, reuses, recycles, and restores materials in production/distribution and consumption processes. The closed-loop system, based on the principles of the circular economy, can operate at the micro-level (products, companies, consumers), meso-level (eco-industrial parks) and macro-level (city, region, country, and beyond) in order to achieve sustainable development-while creating environmental quality, economic prosperity, and social justice-in the interests of present and future generations. This definition can be taken as the conceptual basis of the basic concept as well as the boundaries of use of CE.

Kalmykova et al. [54], after studying a significant number of academic sources of CE, cite the following main definitions of CE in their review.CE is an industrial economy that aims at the use of renewable energy sources, minimizes and eliminates the use of toxic chemicals, and destroys waste through careful design said in the reference [56]. CE focuses on stock optimization and has a three-cycle structure. CE serves for re-use and remarketing for goods, product life extension, and recycling cycle (secondary resources) said in the reference [57]. CE is the economic and industrial system based on the reuse of products and raw materials and the renewal capacity of natural resources, which also seeks to minimize the destruction of value in the common system and maximize the creation of value in every link in the system said in the reference [58]. It is possible to single out a general principle that lies at the heart of these approaches. This is the principle of optimizing reserves, which in turn follows from the limited resources of the Earth.

It is interesting to note that generalizations are laid down in works that compare the concepts of "circular economy", "green economy" and "bioeconomy" as set out in the references [59-61]. D'Amato et al. [59], on the basis of a bibliometric survey of almost two thousand scientific articles published over the past three decades, make the following generalizations: The circular economy and bioeconomics are resource oriented, while the green economy recognizes the central role of all environmental processes. The green economy acts as an umbrella concept, including elements from the circular economy and the concept of bioeconomics (for example, renewable energy sources). 
Geissdoerfer et al. [60] and Martins [61] come to the conclusion that the concept of environmental sustainability unites the circular economy, the green economy, and bioeconomics. It seems to us that it is possible to talk about some common tasks that consider these concepts and which are united by a common ideal for harmonizing economic, ecological, and social goals.

The circular economy is one of the most urgent topics in public discussions of new and more sustainable industrial paradigms and development strategies at the micro-level from practical positions. Veleva and Bodkin [62] Urbinati, Chiaroni, and Chiesa [63] consider that the circular economy is based on the creation of closed-loop systems where resources are reused and stored in a cycle of production and use, which allows us to obtain greater value for a longer period. We get a network of values that allows us to effectively interact with suppliers and carry out the reorganization of our own internal activities.

Franco [64] and Geissdoerfer, Morioka, Carvalho, and Evans [2] offer a mechanism for adapting existing business models of enterprises based on the resource strategy already described. The main idea of this is to keep resources in "use mode" for as long as possible while extracting maximum utility, essentially adapting the existing linear business model of the enterprise to the business concept of the circular economy. Examples of adaptation based on closed-loop systems energy and material cycles can be observed in countries such as Germany and Sweden. It is assumed that the circular economy should be implemented at three functional levels: individual enterprises, eco-industrial parks, and ecological cities/municipalities. At the same time, the three-level economic system formed can minimize the leakage of resources and energy from the system using circular business models and circular supply chain management.

It can be concluded that the business concepts of the circular economy receive a significant impetus among practitioners and researchers for various management objects.

A review of the published literature shows the dominance of studies evaluating the effects of the linear traditional economy on the environment compared to studies evaluating the impact of the circular economy. Proceeding from this, the aim of the present work is to develop methodological provisions based on ecological criteria for assessing the impact of the traditional linear economy on the environment and to use such ecological criteria to develop a methodological approach for assessing the impact of a closed-loop system on the environment.

The concept of comparing the influence of the linear traditional economy and the circular economy on the environment is presented in this article. The core of the concept is a system of interdependent econometric models that reflects the influence of human activity in the economic system on the environment. Endogenous variables of the model are seven estimates of the environment. The exogenous variables of the model are estimates of the economic activity of human activity in the economic system.

Section 2.1 of the article describes the characteristics of the model, justifies the choice of seven endogenous variables of the model, and provides a table that shows the influencing exogenous variables for each endogenous variable.

Section 2.2 of the article describes the methodology for calculating the model parameters.

Section 2.3 of the article suggests conceptual provisions for assessing the influence of the circular economy on the environment.

Section 3 presents results of empirical verification of the model. The analysis of dependence of ecological indicators on human activity within the framework of linear model of economy is carried out.

Section 4 discusses the possibilities of the presented new approach to the definition of environmental criteria for comparing traditional linear and closed-loop systems.

The Conclusions provide information on the possible use of the proposed approach for comparing traditional linear and closed-loop systems. 


\section{Materials and Methods}

In order to simulate the impact of the traditional linear economy on the environment using ecological criteria, we applied the ADL-model toolkit and tested the model using the world economy as an example. In constructing the model of the influence of traditional linear economy on the environment, materials were used as described in References $[25,26]$. The conceptual elements of the dynamic model—reflecting the impact of the traditional linear economy on the environment-consist of seven processes that occur in the environment: global climate change, greenhouse gas emissions, greenhouse gas emissions from agriculture, carbon dioxide $\left(\mathrm{CO}_{2}\right)$ emissions, depletion of freshwater, reduction of forest area, and climatological disasters. A detailed description of these processes can be found in References [65-67].

\subsection{Theoretical Model of the Impact of Traditional Linear Economy on the Environment and Its Characteristics}

In terms of a theoretical model of the impact of linear economy on the environment, a model consisting of seven autoregressive-distributed lags equations (ADL-model) is proposed. In each equation, the current values of the series depend both on the past values of this series and on the current and past values of other time series. Each equation of the ADL model has the form:

$$
y_{t}=a_{0}+\sum_{i=1}^{n} a_{i} y_{t-i}+\sum_{j=0}^{q 1} b_{j} x_{t-i}^{1}+\ldots+\sum_{j=0}^{q k} b_{j} x_{t-i}^{k}+E_{t}
$$

where $k$ - the number of exogenous variables;

$q i$ - the number of lags of the $i$-th exogenous variable $(i=1,2, \ldots, k)$;

$n$-the extent of lags in the endogenous variable;

$E_{t}$ - the remnants forming the process of white noise.

This model indicates that if at some point in time the $t$ independent variable $x$ changes, then this change will affect the values of the variable $y_{t}$ during the subsequent instants of time. The model is generalised in the case of several exogenous variables $x$. In general, we can assume that if all exogenous variables are included in the model with the same number of lags, it is possible to eliminate a lag from some variables.

The dynamic model reflects the impact of the traditional linear economy on the environment. The environment is characterized by seven processes: global climate change, greenhouse gas emissions, greenhouse gas emissions from agriculture, carbon dioxide $\left(\mathrm{CO}_{2}\right)$ emissions, depletion of fresh water, reduction of forest area, and climatic disasters. A detailed description of these processes can be found in References $[65,66]$.

The reason for these processes is a rapid, virtually unregulated population growth. According to the forecast for 2040, the world population will reach 13 billion people. It is clear that with such a rapid increase in the population, the negative consequences of anthropogenic activity will sharply increase. This growth in population will have a negative impact, as it will increase the burden on nature beyond permissible limits. In addition, it will also result in the need to further accelerate the extraction of raw materials in nature, with the consequent increase in their processing, the accumulation of industrial waste and, accordingly, the deleterious effects on the environment. From the above, it can be concluded that the economic activity of a person within the linear economy, which is acquiring an increasingly global character, begins to exert a very tangible influence on the processes taking place in the environment. At the same time, as noted in article [67], the development of sustainable production and consumption models makes the management of environmental problems more efficient while permitting the transformation of environmental constraints into opportunities.

The endogenous model variables are the following seven environmental assessments:

Economic damage from climatological disasters, USD million $\left(y_{t}^{1}\right)$;

Emissions of $\mathrm{CO}_{2}$ into the environment, (grams per USD in constant prices) $\left(y_{t}^{2}\right)$; 
Emissions of greenhouse gases from industry to the environment, tons of $\mathrm{CO}_{2}$ equivalent $\left(y_{t}^{3}\right)$; Emissions of greenhouse gases from agriculture to the environment, tons of $\mathrm{CO}_{2}$ equivalent $\left(y_{t}^{4}\right)$. Change in global temperature, $\% \mathrm{C}\left(y_{t}^{5}\right)$.

Depletion of fresh water supplies, million cubic meters $\left(y_{t}^{6}\right)$.

Reduction of forest cover, sq $\mathrm{km}\left(y_{t}^{7}\right)$.

As exogenous indicators of the model, the results of human activity within the linear economy are considered (Table 1).

Table 1. Indicators of the model.

\begin{tabular}{|c|c|}
\hline Indicators & Description \\
\hline$X_{1+}^{1}$ & GDP, World, US\$ Per Capita \\
\hline$X_{2 t}^{1}$ & Employed Population, World, 000 Unit \\
\hline$X_{3 t}^{1}$ & Economically Active Population, World, 000 Unit \\
\hline$X_{4 t}^{1}$ & Exports (fob) by Commodity + Imports (cif) by Commodity, World, USD million \\
\hline$X_{1 t}^{4^{2}}$ & Energy, Utilities and Recycling: Production (turnover) MSP, USD million \\
\hline$X_{2 t}^{2}$ & $\begin{array}{l}\text { Primary Materials. Forestry. Production (turnover) MSP, USD million (Production volume: } \\
\text { Round wood timber) }\end{array}$ \\
\hline$X_{3+}^{2}$ & Road Freight Traffic. (Volumes of transported goods). World, Million net ton-kilometers \\
\hline$X_{4 t}^{2}$ & Transport and Communications: Production (turnover) MSP, USD million \\
\hline$X_{5 t}^{2}$ & Road Network (road network), Kilometers \\
\hline$X_{6 t}^{2}$ & Material Resource Productivity, USD per kg in constant prices \\
\hline$X_{1 t}^{3}$ & $\begin{array}{l}\text { Emissions of greenhouse gases in the extraction and transportation of coal, oil and gas, } \\
\text { thousand tons of } \mathrm{CO}_{2} \text { equivalent }\end{array}$ \\
\hline$X_{2 t}^{3}$ & Extraction of Crude Petroleum and Natural Gas, USD million \\
\hline$X_{3 t}^{3 t}$ & Mining of Coal and Lignite; Extraction of Peat, USD million \\
\hline$X_{4 t}^{3}$ & $\begin{array}{l}\text { Energy, Utilities and Recycling: Production (turnover) MSP (production of coking } \\
\text { products), USD million }\end{array}$ \\
\hline$X_{5 t}^{3}$ & Railway Freight Traffic, Million ton-kilometers (turnover of railway traffic) \\
\hline$X_{6 t}^{3}$ & Waste Generated by Manufacturing (industrial wastes), thousand tons \\
\hline$X_{1 t}^{4}$ & $\begin{array}{l}\text { World: Machinery for Food, Beverage and Tobacco Processing: Production (turnover) MSP, } \\
\text { USD million }\end{array}$ \\
\hline$X_{2 t}^{4}$ & $\begin{array}{l}\text { World: Machinery. Agricultural and Forestry Machinery: Production (turnover) MSP } \\
\text { (Production of Equipment for Agriculture and Forestry), USD million }\end{array}$ \\
\hline$X_{3 t}^{4}$ & Animal Husbandry. Industrial: Primary Materials. (Livestock: production), USD million \\
\hline$X_{4 t}^{4}$ & Arable Land, thousand sq $\mathrm{km}$ \\
\hline$X_{5 t}^{4 t}$ & Animal Waste-Production (livestock wastes: energy consumption), Terajoules \\
\hline$X_{6 t}^{5 t}$ & Waste Generated by Agriculture, Forestry and Fishing, thousand tons \\
\hline$X_{1+}^{5 t}$ & Methane Emissions ( $\mathrm{kt}$ of $\mathrm{CO}_{2}$ equivalent) \\
\hline$X_{2 t}^{1 t}$ & Nitrous Oxide Emissions (thousand metric tons of $\mathrm{CO}_{2}$ equivalent) \\
\hline$X_{3 t}^{5 t}$ & Greenhouse Gas Emissions, total, thousand tons of $\mathrm{CO}_{2}$ equivalent \\
\hline$X_{4 t}^{5}$ & $\begin{array}{l}\mathrm{CO}_{2} \text { Emissions from the Consumption and Flaring of Fossil Fuels, thousand tons, total } \\
\mathrm{CO}_{2} \text { emissions }\end{array}$ \\
\hline$X_{5 t}^{5}$ & Waste Generated by Electricity, Gas, Steam and Air Conditioning Supply, thousand tons \\
\hline$X_{6 t}^{5 t}$ & Waste Generated by Households, thousand tons \\
\hline$X_{1 t}^{6}$ & Annual freshwater withdrawals (consumption of fresh water, \% of internal resources) \\
\hline$X_{2+}^{1 t}$ & Agricultural Materials and Live Animals Wholesale: Retail and Wholesale, USD million \\
\hline$X_{3 t}^{6 t}$ & Farm Animal Feeds: Production (turnover) MSP, USD million \\
\hline$X_{4 t}^{5 t}$ & Hydrological Disasters (economic damage from hydrological disasters), USD million \\
\hline$X_{5 t}^{4 t}$ & Total population supplied by water industry, $\%$ \\
\hline$X_{6 t}^{6 t}$ & Renewable freshwater resources, million cubic meters \\
\hline$X_{7 t}^{0}$ & Net freshwater supplied by water supply industry, million cubic meters \\
\hline$X_{1 t}^{7^{t}}$ & Agricultural Land Area, thousand sq km \\
\hline$X_{2 t}^{1 t}$ & Total Population, thousand people \\
\hline$X_{3 t}^{7^{i}}$ & Wood and Paper Products: Production (turnover) MSP, USD million \\
\hline
\end{tabular}

The interdependence of the endogenous and exogenous variables of the model is reflected in Table 2. 
Table 2. Interdependence of endogenous and exogenous variables.

\begin{tabular}{ccccccccc}
\hline Endogenous Variables & \multicolumn{7}{c}{ Exogenous Variables } \\
\hline$y_{t}^{1}$ & $X_{1 t}^{1}$ & $X_{2 t}^{1}$ & $X_{3 t}^{1}$ & $X_{4 t}^{1}$ & & & \\
$y_{t}^{2}$ & $Y_{7 t}^{1}$ & $X_{1 t}^{2}$ & $X_{2 t}^{2}$ & $X_{3 t}^{2}$ & $X_{4 t}^{2}$ & $X_{5 t}^{2}$ & $X_{6 t}^{2}$ & \\
$y_{t}^{3}$ & $X_{1 t}^{3}$ & $X_{2 t}^{3}$ & $X_{3 t}^{3}$ & $X_{4 t}^{3}$ & $X_{5 t}^{3}$ & $X_{6 t}^{3}$ & & \\
$y_{t}^{4}$ & $X_{1 t}^{4}$ & $X_{2 t}^{4}$ & $X_{3 t}^{4}$ & $X_{4 t}^{4}$ & $X_{5 t}^{4}$ & $X_{6 t}^{4}$ & & \\
$y_{t}^{5}$ & $X_{1 t}^{5}$ & $X_{2 t}^{5}$ & $X_{3 t}^{5}$ & $X_{4 t}^{5}$ & $X_{5 t}^{5}$ & $X_{6 t}^{5}$ & & \\
$y_{t}^{6}$ & $Y_{7 t}^{6}$ & $X_{1 t}^{6}$ & $X_{2 t}^{6}$ & $X_{3 t}^{6}$ & $X_{4 t}^{6}$ & $X_{5 t}^{6}$ & $X_{6 t}^{6}$ & $X_{7 t}^{6}$ \\
$y_{t}^{7}$ & $X_{1 t}^{7}$ & $X_{2 t}^{7}$ & $X_{3 t}^{7}$ & & & & & \\
\hline
\end{tabular}

\subsection{Method for Empirically Verifying the Effect of Linear Economy on the External Environment}

The methodology includes a sequence of methods and procedures that are performed when constructing the model and obtaining model parameters. The main ones include: checking time series for stationarity using the Dickey-Fuller test; choice of exogenous variables using the test for multicollinearity; choice of endogenous variable lags, which have a strong correlation with the value of the variable during the previous period; transformation of the structural form of the model to a reduced form by means of linear transformations; verification of the identifiability of a system of equations; checking the significance of the regression model using Fisher's F-criteria and regression coefficients using Student's $t$-criteria.

Data for the empirical verification of the model were collected over the period 1998 to 2015. The data contain the values of endogenous and exogenous variables for the corresponding year for the countries of the world. The data were taken from the References $[68,69]$.

The structural form of the model is written as follows (2):

$$
\left\{\begin{array}{c}
y_{t}^{1}=f\left(y_{t-j}^{1}, X_{1 t}^{1}, X_{2 t}^{1}, X_{3 t}^{1}, X_{4 t}^{1}\right) \\
y_{t}^{2}=f\left(y_{t-j}^{2}, y_{t}^{7}, X_{1 t}^{2}, X_{2 t}^{2}, X_{3 t}^{2}, X_{4 t}^{2}, X_{5 t}^{2}, X_{6 t}^{2}\right) \\
y_{t}^{3}=f\left(y_{t-j}^{3}, X_{1 t}^{3}, X_{2 t}^{3}, X_{3 t}^{3}, X_{4 t}^{3}, X_{5 t}^{3}, X_{6 t}^{3}\right) \\
y_{t}^{4}=f\left(y_{t-j}^{4}, X_{1 t}^{4}, X_{2 t}^{4}, X_{3 t}^{4}, X_{4 t}^{4}, X_{5 t}^{4}, X_{6 t}^{4}\right) \\
y_{t}^{5}=f\left(y_{t-j}^{5}, X_{1 t}^{5}, X_{2 t}^{5}, X_{3 t}^{5}, X_{4 t}^{5}, X_{5 t}^{5}, X_{6 t}^{5}\right) \\
y_{t}^{6}=f\left(y_{t-j}^{6}, y_{t}^{7}, X_{1 t}^{6}, X_{2 t}^{6}, X_{3 t}^{6}, X_{4 t}^{6}, X_{5 t}^{6}, X_{6 t}^{6}\right) \\
y_{t}^{7}=f\left(y_{t-j}^{7}, X_{1 t}^{7}, X_{2 t}^{7}, X_{3 t}^{7}\right)
\end{array}\right\}
$$

The necessary condition for the identifiability of the equation can be written in the form of the following counting rule:

$$
\begin{gathered}
\mathrm{D}+1=\mathrm{H} \text {-the equation is identifiable; } \\
\mathrm{D}+1<\mathrm{H} \text {-the equation is not identifiable; } \\
\mathrm{D}+1>\mathrm{H} \text {-the equation is overidentified; }
\end{gathered}
$$

where $\mathrm{H}$ - the number of endogenous variables in the $i$-th equation of the system; $\mathrm{D}$ - the number of exogenous variables that are contained in the system but not entered into this equation.

A sufficient condition for identification is determined by imposing restrictions on the parameter matrix coefficients of the structural model. The equation is identifiable if-according to variables that are not present in it (endogenous and exogenous) - one can obtain from the coefficients for them in other equations of the system, a matrix whose determinant is not zero and whose rank is not less than the number of endogenous variables in the system minus one. With the overidentified model, the system of equations is solved using the two-stage least squares method. 


\subsection{Conceptual Provisions of the Analysis of the Influence of Closed-Loop Systems on the External Environment}

Conceptual provisions of the analysis of the influence of closed-loop systems on the external environment include the following provisions: (a) As the theoretical model of the influence of closed-loop systems on the environment, the same autoregressive distributed lags (ADL) model remains with the same endogenous and exogenous variables. (b) Using the situational modeling tools, the exogenous model variables are presented as cycles (loops) to determine the estimated exogenous variables. (c) Estimated exogenous variables are used to determine the impact of the estimated variables of a circular economy on environmental variables.

According to the principles of a circular economy, recycling can be beneficial to the world economy by creating new jobs, saving resources, and preventing waste. Depending on the concept of its development, the circular economic model can be characterized in the same way as the traditional linear economy in terms of the powerful anthropogenic impact of people on the environment. The goal of closed-loop modeling is to determine the value of exogenous variables for each equation. In terms of business strategies and types of technologies that can display a circular economy and which will be modeled, five business strategies and three types of technologies, designated by the World Business Council for Sustainable Development, are planned. In terms of business strategies, technologies experts writing in the CEO Guide to the Circular Economy at the World Circular Economy Forum propose the following: that companies use renewable energy and biological or recyclable materials; extract useful resources from materials, by-products and waste; increase the life cycle of goods, repairing it, modernizing, and reselling with the help of innovations and thoughtful design; acquaint consumers with each other and motivate them to jointly own goods; encourage buyers to purchase access to a product rather than the product itself. Among other useful technologies, the experts distinguish digital, physical, and biological approaches: Internet of things; technology for distributed information storage (blockchain); automatic RFID identification systems for RFID objects; mechanisms for analyzing big data, allowing companies to track the supply of raw materials and waste management; 3D printing; robotics; nanotechnology, helping to reduce the cost of production of goods; biotechnology, such as bioenergetics, biocatalysis, hydroponics, giving companies the opportunity to replace fossil energy sources.

As a mathematical tool for modeling recirculation, the authors selected a dynamic systems computer simulation approach. When solving such problems, it is necessary to evaluate a large number of parameters. The modeling is based on the construction of graphical diagrams and the inclusion in the model of all relevant loops of feedback, delay, and uncertainty. The approach used is to first construct a simple model of the situation and then build it up with various elements, thereby expanding the scope of the process. It is anticipated that the components of the model will interact with each other and that such interactions will generate feedback processes. Feedback describes a process in which one component of the model initiates changes in other components, and these changes lead to additional changes in the component that originally initiated the changes. At the same time, the authors encounter various nonlinear feedback processes, some with random disturbances that lead to complex system behavior.

For the modeling software, the authors selected iThink can be found in References [70], which employs an iconographic style of programming. The entire dynamic model in iThink can be considered in terms of a single regression equation, which can be used in statistical analysis to optimize some indicator. Statistical analysis does not participate in optimizing selected indicators to complete the dynamic modeling process but is the key to finding the initial parameters for these models.

\section{Results}

The developed modeling approach makes it possible to establish a system of interrelations between environmental variables as well as determine the character of the impact of the traditional linear economy on the environment. Taking into account the results of the conducted procedures for 
verifying the time series for stationarity and selecting exogenous variables and endogenous variable lags, the structural form of the model is given as (3):

$$
\left\{\begin{array}{c}
y_{t}^{1}=\alpha_{0}+\alpha_{1} y_{t-1}^{1}+\alpha_{2} x_{1, t}^{1}+\alpha_{3} x_{2, t}^{1}+\alpha_{4} x_{3, t}^{1}+\alpha_{5} x_{4, t}^{1}+\alpha_{6} x_{4, t-1}^{1} \\
y_{t}^{2}=\alpha_{0}+\alpha_{1} y_{t-1}^{2}+\alpha_{2} y_{t}^{7}+\alpha_{3} y_{t-1}^{7}+\alpha_{4} x_{2, t}^{2}+\alpha_{5} x_{4, t}^{2}+\alpha_{6} x_{5, t}^{2}+\alpha_{7} x_{6, t}^{2} \\
y_{t}^{3}=\alpha_{0}+\alpha_{1} y_{t-1}^{3}+\alpha_{2} x_{1, t}^{3}+\alpha_{3} x_{3, t}^{3}+\alpha_{4} x_{3, t-1}^{3}+\alpha_{5} x_{5, t}^{3}+\alpha_{6} x_{5, t-1}^{3}+\alpha_{6} x_{6, t}^{3} \\
y_{t}^{4}=\alpha_{0}+\alpha_{1} y_{t-1}^{4}+\alpha_{2} x_{1, t}^{4}+\alpha_{3} x_{1, t-1}^{4}+\alpha_{4} x_{2, t}^{4}+\alpha_{5} x_{4, t}^{4}+\alpha_{6} x_{5, t}^{4}+\alpha_{7} x_{6, t}^{4} \\
y_{t}^{5}=\alpha_{0}+\alpha_{1} y_{t-1}^{5}+\alpha_{2} x_{1, t}^{5}+\alpha_{3} x_{2, t}^{5}+\alpha_{4} x_{3, t}^{5}+\alpha_{5} x_{5, t}^{5}+\alpha_{6} x_{6, t}^{5} \\
y_{t}^{6}=\alpha_{0}+\alpha_{1} y_{t-1}^{6}+\alpha_{2} y_{t}^{7}+\alpha_{3} y_{t-1}^{7}+\alpha_{4} x_{1, t}^{6}+\alpha_{5} x_{4, t}^{6}+\alpha_{6} x_{5, t}^{6}+\alpha_{7} x_{6, t}^{6}+\alpha_{8} x_{7, t}^{6} \\
y_{t}^{7}=\alpha_{0}+\alpha_{1} y_{t-1}^{7}+\alpha_{2} x_{1, t}^{7}+\alpha_{3} x_{1, t-1}^{7}+\alpha_{4} x_{2, t}^{7}+\alpha_{5} x_{2, t-1}^{7}+\alpha_{6} x_{3, t}^{7}
\end{array}\right\}
$$

Applying the procedure for the identifiability of a system of equations revealed that according to the necessary and sufficient condition, the equations of the system are overidentified. Consequently, it was necessary to apply the two-stage least squares method.

Obtaining the coefficients of the regression equations and evaluating the significance of the regression model using Fisher's F-test and the coefficients of the regression equation with the help of Student's $t$-test allows us to write the model in the following form (4):

$$
\left\{\begin{array}{c}
y_{t}^{1}=30338.4+0.38443 y_{t-1}^{1}+2.15697 x_{1, t}^{1} \\
+0.09402 x_{2, t}^{1}+0.068862 x_{3, t}^{1}+0.002106 x_{4, t}^{1}+0.00171 x_{4, t-1}^{1} \\
y_{t}^{2}=40595.801+0.83918843 y_{t-1}^{2}-0.1951036 y_{t}^{7}-0.8425688 y_{t-1}^{7} \\
-0.0329481 x_{2, t}^{2}+0.00099917 x_{4, t}^{2}-0.0001064 x_{5, t}^{2}+4840.1371 x_{6, t}^{2} \\
y_{t}^{3}=-32108.1+0.100166 y_{t-1}^{3}+3.477275 x_{1, t}^{3}+0.000287 x_{3, t}^{3} \\
+0.004987 x_{3, t-1}^{3}-0.50132 x_{5, t}^{3}-0.011968 x_{5, t}^{3}+0.00221 x_{6, t}^{3} \\
y_{t}^{4}=46830.59+0.236461 y_{t-1}^{4}-0.04916 x_{1, t}^{4}-0.02082 x_{1, t-1}^{4} \\
+0.015105 x_{2, t}^{4}-0.02238 x_{4, t}^{4}-16.2508 x_{5, t}^{4}+0.014792 x_{6, t}^{4} \\
y_{t}^{5}=5.7590205+0.7258157 y_{t-1}^{5}-5.46 \mathrm{E}-10 x_{1, t}^{5} \\
+4.453 \mathrm{E}-08 x_{2, t}^{5}-1.1 \mathrm{E}-06 x_{3, t}^{5}+2.191 \mathrm{E}-06 x_{5, t}^{5}+2.06 \mathrm{E}-06 x_{6, t}^{5} \\
y_{t}^{6}=112772.6297+0.08271 y_{t-1}^{6}-13.45141671 y_{t}^{7}+12.54696 y_{t-1}^{7} \\
-23.04829 x_{1, t}^{6}+0.06126 x_{4, t}^{6}-32.827 x_{5, t}^{6}+12.902359 x_{6, t}^{6}-45.96172 x_{7, t}^{6} \\
y_{t}^{7}=33990.95+0.00656 y_{t-1}^{7}+0.1885 x_{1, t}^{7}+0.02673 x_{1, t-1}^{7} \\
-0.013334 x_{2, t}^{7}-0.01372 x_{2, t-1}^{7}+0.000028 x_{3, t}^{7}
\end{array}\right\}
$$

As a result, a model is obtained that describes the influence of the traditional linear economy on the environment. The model variable relationships can be noted as follows.

Analysis of the climatic catastrophe variable has demonstrated a positive dependency of the endogenous variable on its past values. In other words, a large number of climatic catastrophes generate an even greater number of catastrophes. Exogenous variables did not demonstrate a dependency on past periods. However, all exogenous parameters have a positive correlation with the endogenous ones. That is to say, growth in global GDP and employment, an increase in the economically active population, and expansion of global exports and imports of goods lead to an increase in climatic disasters. Thus, global increases in basic economic indicators translate into a higher number of environmental problems. This points to the necessity of introducing the principles of the circular economy with the aim of reducing ecological damage.

$\mathrm{CO}_{2}$ emissions per unit of production also reflect the dependency on the past period. This dependency, similar to the previous example, is positive; that is, the more emissions now, the greater they will be in the future. The endogenous variable is also influenced by another endogenous variable-reduction in forest cover. The negative relationship between them, both in the current and the past period, is entirely explicable. Two indicators-the volume of freight traffic as well as the volume of production and processing of energy-were removed from the analysis due to the high 
degree of correspondence with other exogenous variables. The remaining variables demonstrate the following impact on the amount of $\mathrm{CO}_{2}$ emissions: Indicators of transport and communications as well as the productivity of material resources lead to an increase in the amount of $\mathrm{CO}_{2}$ emissions. Indicators of production of round timber as well as an increase in the road network conversely lead to a reduction in emissions. No exogenous variables demonstrate a dependency on past periods.

By analogy to past indicators, industrial greenhouse gas emissions demonstrate a positive dependency on the past period; hence, with unchanged production, there is a potential for an increase in emissions. Exogenous variables demonstrate no dependency on past periods. Of all those considered, the only variable whose increase leads to a reduction in industrial greenhouse gas emissions is rail traffic turnover. Increases in the remainder-namely, greenhouse gas emissions in the extraction and transportation of coal, oil and gas, coal and lignite mining, waste generated from industry-lead to an increase in greenhouse gas emissions from industry.

In common with the already considered variables, greenhouse gas emissions from agriculture depend positively on past periods. The production of equipment for agriculture and forestry, as well as waste generated from agriculture, leads to an increase in greenhouse gas emissions from agriculture, which is in accordance with expectations. The remaining variables, conversely, curb growth of emissions. The production of equipment for the food industry, production of beverages and tobacco processing, increase in arable land, livestock waste, and energy consumption reduce the volume of emissions, curbing the deterioration of the environmental situation in the agricultural sector. The indicator of livestock breeding was removed from the analysis due to exhibiting a high degree of connection with the variables under consideration.

The variable of global temperature change increases over time, reflecting the dependence on the eigenvalue in the past period. The growth of the variable of change in global temperature is influenced by an increase in emissions of nitrous oxide, an increase in waste generated from electricity, gas, steam and air conditioning as well as an increase in waste generated by households. The volume of methane and greenhouse gas emissions reflects the inverse relationship with the endogenous variable. It should be noted that the volume of $\mathrm{CO}_{2}$ emissions from the consumption and combustion of fossil fuels was removed from the analysis due to its strong connection with all the influencing variables.

Like the other endogenous variables, the reduction in the volume of fresh water positively depends on its value in the past period; that is, an increase in extraction in the previous year will lead to an even greater volume of extraction in the current year. The variable shows a dependency on the reduction of the forest area; however, this dependency varies according to different time periods. During the previous period, forestation is reduced by the extraction of fresh water; conversely, reduced forest cover stimulates extraction during the current period. Indicators of retail and wholesale trade in live animals and agricultural materials, as well as turnover of animal feed, were removed from the analysis. The remaining variables demonstrated the following influence on the endogenous parameter: Renewable freshwater resources, as well as economic damage from hydrological disasters, lead to an increase in extraction of fresh water. Whereas annual freshwater wastes-the net quantity of fresh water supplied to industry-exhibit an inverse relationship.

The reduction of forest cover in the current period, as well as other endogenous variables, will lead to an even greater reduction in the future. In addition, the endogenous variable is affected by the area of agricultural land, the total population as well as the production of pulp and paper products. Only total population negatively impacts on the reduction in forest cover. The remaining indicators stimulate such a reduction.

Analyzing the dependency of environmental indicators on human activities according to the traditional linear economy model, we can conclude that most vital processes entail considerable damage to the environment. The primary economic processes stimulate the amplification of environmental problems. There is an incontrovertible need to introduce the principles of the circular economy with the aim of reducing ecological damage. 
Can the closed-loop systems arrest or reduce the negative impacts of the traditional linear economic model on the current state of the environment? Is it possible to create a circular ecological system?

In the opinion of the authors of the present article, the answer to the above questions can be obtained using the procedure for modeling the influence of the traditional linear economy on the environment. The model will show the dependence of endogenous variables evaluating the state of the environment on the exogenous variables that characterize the traditional linear economy. By transforming the exogenous variables evaluating the traditional linear economy in the model into exogenous variables evaluating the closed-loop systems, it is possible to analyze changes in variables that evaluate the state of the external environment.

\section{Discussion}

In the global economy, which is characterized by increasing industrial production and increased human impact on the environment, issues of measuring and analyzing various relationships between the environment, the economy, industrial policies, and human actions continue to be actively debated in References [17-19,23].

The study of the relationships between the environment, the economy, and industrial policies is usually focused on identifying the impact of individual factors on the environment, including anthropogenic influences outlined in References [13,16], the growth of urbanization outlined in Reference [10], and changes in technological standards outlined in References [11,12]. While this approach permits a determination of the level of emerging risks for the environment, it does not help us to understand how to make the transition from an economic model that develops linearly to one that develops as a closed-loop system written by D'Amato et al [59]. Principally, the results of this study allow the establishment of a system of interrelations between the selected indicators used to evaluate the environment. Further, after establishing the nature of the influence of the economy on the environment with the tools of the traditional linear economy, it is possible to proceed to an assessment of the impact of the circular economy model on the environment. Nevertheless, research on the influence of income factors, production technologies in References $[9,25]$, and environmental quality in Reference [23] on economic growth indicators as a reverse process is gaining currency. However, these results are mainly characteristic of the convergence processes for identical economies. Our methodological approach permits the use of environmental criteria to evaluate the complex influence of the traditional linear economy as the converse of the circular economic model (closed-loop systems) on the environment.

Models of the influence of the traditional linear economy on the environment, including the influence of human civilization on the Earth's climate, the effect of biomass consumption on $\mathrm{CO}_{2}$ emissions as well as recommendations for reducing the global emission of $\mathrm{CO}_{2}$ and other greenhouse gases are fairly well known in References [3,5-7]. Our result differs from the standard result in that by analyzing the main sources of air pollution (enterprises of the fuel and energy complex, manufacturing industry, and transport), it is possible to use environmental criteria as a tool for comparing the impacts of the traditional linear economy and the circular economy (closed-loop systems) on the environment.

\section{Conclusions}

A generalized conclusion of research studies noted in the introduction shows that the problem of a complex assessment of the influence of the traditional linear economy model as the converse of the circular economic model (closed-loop systems) on the environment and the impact of the circular economy model (closed-loop systems) on the environment using environmental criteria and tools for cycling was not investigated within the framework of the set of tools proposed in the present article. An exception to this is Reference [71], where the short- and long-term consequences of the impact of income inequality, economic growth, domestic investment, trade openness, and energy consumption as economic factors in different countries were investigated using the ADL model. 
This article formulates the methodological idea of looping using the mathematical toolkit of computer modeling of dynamic systems (iThink) using Reference [70], which permits an assessment of the impact and highlights possible negative effects of the circular economic model (closed-loop systems) on the environment. The toolkit of the cycling of exogenous modeled variables presented in the article uses technologies that meet the requirements of a circular economy. Methodological provisions that permit an evaluation of the integrated influence of the traditional linear economic model on the environment were tested and brought to a concrete conclusion.

The results of the research presented in this article can be used in scientific research and practical activities of institutions related to the analysis, control, and regulation of the impact of human activities on the environment. In scientific research, it is important to develop a mathematical tool for transformational transition from a traditional linear economic model to a circular economic model, selecting various exogenous variable models that meet the requirements of a circular economy.

In practice, the methodology can be used to develop a model of the dependency of environmental indicators on human activities in a traditional linear economy. A model that shows the impact of human activities on environmental indicators can be developed for various objects and territories and used for analysis, control and regulation of processes in the environment: for individual firms, municipalities, regions of the country, regions of the world, and the global economy as a whole. The only limitation to the construction of a model for exactly such endogenous and exogenous variables as set out in the article is the absence of some relevant statistical information in the databases of various countries. In this case, the model can either exchange endogenous and exogenous variables or its authors can organize the collection of the missing information.

Author Contributions: The authors contributed equally to this work.

Funding: This research was funded by the Russian Science Foundation (Project No. 14-38-00009, The program targeted management of the Russian Arctic zone development, Peter the Great St. Petersburg Polytechnic University). The Russian Science Foundation, 109992, Russian Federation, Moscow, http: / rscf.ru/.

Acknowledgments: The paper is based on research carried out with the financial support of a grant from the Russian Science Foundation (Project No. 14-38-00009, The program targeted management of the Russian Arctic zone development) and Peter the Great St. Petersburg Polytechnic University.

Conflicts of Interest: The authors declare no conflict of interest.

\section{References}

1. Michelini, G.; Moraes, R.N.; Cunha, R.N.; Costa, J.-M.H.; Ometto, A.R. From Linear to Circular Economy: PSS Conducting the Transition. Proced. CIRP 2017, 64, 2-6. [CrossRef]

2. Geissdoerfer, M.; Morioka, S.N.; Carvalho, M.M.; Evans, S. Business models and supply chains for the circular economy. J. Clean. Prod. 2018, 190, 712-721. [CrossRef]

3. Magaril, E.R.; Abrzhina, L.L.; Belyaeva, M.A. Environmental damage from the combustion of fuels: Challenges and methods of economic assessment. WIT Trans. Ecol. Environ. 2014, 190, 1105-1115.

4. Magaril, E.; Magaril, R.; Panepinto, D.; Genon, G.; Ravina, M.; Trushkova, L.; Zanetti, M.C. Production and utilization of energy and climate adaptation: Global tasks and local routes. Int. J. Sustain. Dev. Plan. 2017, 12, 1326-1337. [CrossRef]

5. Panepinto, D.; Zanetti, M.C.; Gitelman, L.; Kozhevnikov, M.; Magaril, E.; Magaril, R. Energy from Biomass for Sustainable Cities. IOP Conf. Ser. Earth Environ. Sci. 2017, 72, 012021. [CrossRef]

6. Schiavon, M.; Redivo, M.; Antonacci, G.; Rada, E.C.; Ragazzi, M.; Zardi, D.; Giovannini, L. Assessing the air quality impact of nitrogen oxides and benzene from road traffic and domestic heating and the associated cancer risk in an urban area of Verona (Italy). Atmos. Environ. 2015, 120, 234-243. [CrossRef]

7. Cioca, L.-I.; Ivascu, L.; Rada, E.C.; Torretta, V.; Ionescu, G. Sustainable development and technological impact on $\mathrm{CO}_{2}$ reducing conditions in Romania. Sustainability (Switzerland) 2015, 7, 1637-1650. [CrossRef]

8. Istrate, I.A.; Oprea, T.; Rada, E.C.; Torretta, V. Noise and air pollution from urban traffic. WIT Trans. Ecol. Environ. 2014, 191, 1381-1389. 
9. Ragazzi, M.; Ionescu, G.; Cioranu, S.I. Assessment of environmental impact from renewable and non-renewable energy sources. Int. J. Energy Prod. Manag. 2017, 2, 8-16. [CrossRef]

10. Tashlykov, O.; Shcheklein, S.; Nosov, Y.; Smyshlaeva, O. Ecological foresight in the nuclear power of XXI century. Int. J. Energy Prod. Manag. 2017, 1, 133-140. [CrossRef]

11. Aja, O.C.; Al-Kayiem, H.H. Review of municipal solid waste management options in Malaysia, with an emphasis on sustainable waste-to-energy options. J. Mater. Cycles Waste Manag. 2014, 16, 693-710. [CrossRef]

12. Sedghkerdar, M.H.; Mahinpey, N. A modified grain model in studying the $\mathrm{CO}_{2}$ capture process with a calcium-based sorbent: A semianalytical approach. Ind. Eng. Chem. Res. 2015, 54, 869-877. [CrossRef]

13. Gudmestad, O.; Traa, K. Sustainable use and production of energy in the 21st century. Int. J. Energy Prod. Manag. 2015, 1, 1-15. [CrossRef]

14. Grossman, G.M.; Krueger, A.B. Environmental Impacts of a North American Free Trade Agreement. NBER Work. 1991, 3914. [CrossRef]

15. Lopez, R. The Environment as a Factor of Production: The Effects of Economic Growth and Trade Liberalization. J. Environ. Econ. Manag. 1994, 27, 163-184. [CrossRef]

16. McConnell, K.E. Income and the Demand for Environmental Quality. Environ. Dev. Econ. 1997, 22, 383-399. [CrossRef]

17. Andreoni, J.; Levinson, A. The Simple Analytics of the Environmental Kuznets Curve. J. Public Econ. 2001, 80, 269-286. Available online: http:/ / econweb.ucsd.edu/ jandreon/Publications/JPubEKuznets.pdf (accessed on 20 January 2017). [CrossRef]

18. Grossman, G.M.; Krueger, A.B. Economic growth and the environment. Q. J. Econ. 1995, 110, $353-377$. [CrossRef]

19. Chimeli, A.B.; Braden, J.B. A Capital Scarcity Theory of the Environmental Kuznets Curve. Environ. Dev. Econ. 2009, 14, 541-564. [CrossRef]

20. Lahiri, B. Dissimilar Relations between Income and Environmental Quality for Open Economies in a Growth Model. East. Econ. J. 2017, 43, 104-127. [CrossRef]

21. Miglietta, P.P.; Leo, F.; Toma, P. Environmental Kuznets curve and the water footprint: An empirical analysis. Water Environ. J. 2017, 31, 20-30. [CrossRef]

22. Stokey, N.L. Are There Limits to Growth? Int. Econ. Rev. 1998, 39, 1-31. [CrossRef]

23. May, G.; Stahl, B.; Taisch, M. Energy management in manufacturing: Toward eco-factories of the future-A focus group study. Appl. Energy 2016, 164, 628-638. [CrossRef]

24. Carson, R.T. The Environmental Kuznets Curve: Seeking Empirical Regularity and Theoretical Structure. Rev. Environ. Econ. Policy 2010, 4, 3-23. [CrossRef]

25. Didenko, N.; Rudenko, D.; Skripnuk, D. Environmental security issues in the Russian Arctic. Int. Multidiscip. Sci. GeoConf. Surv. Geol. Min. Ecol. Manag. SGEM Albena 2015, 3, 267-274.

26. Didenko, N.; Skripnuk, D.; Krasulina, O. Modelling the spatial development of the Russian Barents-Arctic Region. SGEM Int. Multidiscip. Sci. Conf. Soc. Sci. Arts Sofia Bulgaria 2016, 5, 471-478.

27. Izraehl', Y.A. O sostoyanii sovremennogo klimata i predpolozheniya o deyatel'nosti v oblasti protivodejstviya izmeneniyu klimata. ZHurnal Metrol. Gidrol. 2008, 10, 5-8.

28. Belay, A.; Recha, J.W.; Woldeamanuel, T.; Morton, J.F. Smallholder farmers' adaptation to climate change and determinants of their adaptation decisions in the Central Rift Valley of Ethiopia. Agric. Food Secur. 2017, 6, 24. [CrossRef]

29. Bekhet, H.A.; Othman, N.S. Impact of urbanization growth on Malaysia $\mathrm{CO}_{2}$ emissions: Evidence from the dynamic relationship. J. Clean. Prod. 2017, 154, 374-388. [CrossRef]

30. Kumar, M.; Gogoi, A.; Kumari, D.; Borah, R.; Das, P.; Mazumder, P.; Tyagi, V.K. Review of perspective, problems, challenges, and future scenario of metal contamination in the urban environment. J. Hazard. Toxic Radioact. Waste 2017, 21, 04017007. [CrossRef]

31. Sang, Y.N.; Bekhet, H.A. Modelling electric vehicle usage intentions: An empirical study in Malaysia. J. Clean. Prod. 2015, 92, 75-83. [CrossRef]

32. Karl, T.R.; Trenberth, K.E. The human impact on climate. Sci. Am. 1999, 281, 100-105. [CrossRef]

33. Bilgili, F.; Koçak, E.; Bulut, Ü.; Kuşkaya, S. Can biomass energy be an efficient policy tool for sustainable development. J. Renew. Sustain. Energy Rev. 2017, 71, 830-845. [CrossRef] 
34. Waha, K.; Krummenauer, L.; Adams, S.; Aich, V.; Baarsch, F.; Coumou, D.; Fader, M.; Hoff, H.; Jobbins, G.; Marcus, R.; et al. Climate change impacts in the Middle East and Northern Africa (MENA) region and their implications for vulnerable population groups. J. Reg. Environ. Chang. 2017, 17, 1623-1638. [CrossRef]

35. Ridzuan, A.R.; Ismail, N.A.; Hamat, A.F.C.; Md Nor, A.H.S.; Ahmed, E.M. Does equitable income distribution influence environmental quality? Evidence from developing countries of ASEAN-4. J. Pertanika J. Soc. Sci. Humanit. 2017, 25, 385-400.

36. Maier, S.; Szerencsits, M.; Shahzad, K. Ecological evaluation of biogas from catch crops with Sustainable Process Index (SPI). J. Energy Sustain. Soc. 2017, 7, 4. [CrossRef]

37. Summers, J.C.; Kurek, J.; Rühland, K.M.; Neville, E.E.; Smol, J.P. Assessment of multi-trophic changes in a shallow boreal lake simultaneously exposed to climate change and aerial deposition of contaminants from the Athabasca Oil Sands Region, Canada. Sci. Total Environ. 2017, 592, 573-583. [CrossRef] [PubMed]

38. Sakadevan, K.; Nguyen, M.-L. Livestock Production and Its Impact on Nutrient Pollution and Greenhouse Gas Emissions. J. Adv. Agron. 2017, 141, 147-184.

39. Liu, P.; Hao, L.; Pan, C.; Zhou, D.; Liu, Y.; Sun, G. Combined effects of climate and land management on watershed vegetation dynamics in an arid environment. Sci. Total Environ. 2017, 589, 73-88. [CrossRef] [PubMed]

40. Herzog, F.; Lüscher, G. European farm scale habitat descriptors for the evaluation of biodiversity. Ecol. Indic. 2017, 77, 205-217. [CrossRef]

41. Ellis, R.P.; Urbina, M.A.; Wilson, R.W. Lessons from two high $\mathrm{CO}_{2}$ worlds-future oceans and intensive aquaculture. Glob. Chang. Biol. 2017, 23, 2141-2148. [CrossRef] [PubMed]

42. Liu, J.; Li, J.; Qin, K.; Zhou, Z.; Yang, X.; Li, T. Changes in land-uses and ecosystem services under multi-scenarios simulation. Sci. Total Environ. 2017, 586, 522-526. [CrossRef] [PubMed]

43. Riti, J.S.; Shua, Y.; Songa, D.; Kamah, M. The contribution of energy use and financial development by source in climate change mitigation process: A global empirical perspective. J. Clean. Prod. 2017, 148, 882-894. [CrossRef]

44. Gelfan, A.; Gustafsson, D.; Motovilov, Y.; Arheimer, B.; Kalugin, A.; Krylenko, I.; Lavrenov, A. Climate change impact on the water regime of two great Arctic rivers: Modeling and uncertainty issues. Clim. Chang. 2017, 141, 499-515. [CrossRef]

45. Millar, C.I.; Stephenson, N.L.; Scott, S.L. Climate change and forests of the future: Managing in the face of uncertainty. Ecol. Appl. 2007, 17, 2145-2151. [CrossRef] [PubMed]

46. Hinzman, L.D.; Bettez, N.D.; Bolton, W.R.; Chapin, F.S.; Dyurgerov, M.B.; Fastie, C.L.; Griffith, B.; Hollister, R.D.; Hope, A.; Huntington, H.P. Evidence and implications of recent climate change in northern Alaska and other arctic regions. Clim. Chang. 2005, 72, 251-298. [CrossRef]

47. Wang, G.; Yang, K.; Yang, Y.; Zhang, S. Coupling natural and human processes to simulate changes in the water environment. Geosyst. Eng. 2017, 20,1-9. [CrossRef]

48. Pasiakos, S.M.; Agarwal, S.; Lieberman, Y.R.; Fulgoni, V.L. Sources and amounts of animal, dairy, and plant protein intake of US adults in 2007-2010. Nutrients 2015, 7, 7058-7069. [CrossRef] [PubMed]

49. Horvath, B.; Mallinguh, E.; Fogarassy, C. Designing Business Solutions for Plastic Waste Management to Enhance Circular Transitions in Kenya. Sustainability 2018, 10, 1664. [CrossRef]

50. Ilić, M.; Nikolić, M. Drivers for development of circular economy-A case study of Serbia. Habitat Int. 2016, 56, 191-200. [CrossRef]

51. Saavedra, Y.M.B.; Iritani, D.; Pavan, A.L.; Ometto, A. Theoretical contribution of industrial ecology to circular economy. J. Clean. Prod. 2018, 170, 1514-1522. [CrossRef]

52. Fogarassy, C.; Horvath, B.; Kovacs, A.; Szoke, L.; Takacs-Gyorgy, K.A. Circular Evaluation Tool for Sustainable Event Management-An Olympic Case Study. Acta Polytech. Hung. 2017, 14, 161-177.

53. Korhonen, J.; Honkasalo, A.; Seppälä, J. Circular Economy: The Concept and its Limitations. Ecol. Econ. 2018, 143, 37-46. [CrossRef]

54. Kalmykova, Y.; Sadagopan, M.; Rosado, L. Circular economy-From review of theories and practices to development of implementation tools Resources. Conserv. Recycl. 2018, 135, 190-201. [CrossRef]

55. Kirchherr, J.; Reike, D.; Hekkert, M. Conceptualizing the circular economy: An analysis of 114 definitions. Resour. Conserv. Recycl. 2017, 127, 221-232. [CrossRef]

56. EMF. Delivering the Circular Economy a Toolkit for Policymakers. 2015. Available online: http://www. ellenmacarthurfoundation.org (accessed on 22 November 2017). 
57. Stahel, W.R. Policy for material efficiency—Sustainable taxation as a departure from the throwaway society. philosophical transactions of the royal society a: Mathematical. Phys. Eng. Sci. 2013, 371. [CrossRef] [PubMed]

58. Bastein, T.; Roelofs, E.; Rietveld, E.; Hoogendoorn, A. Opportunities for a Circular Economy in the Netherlands. 2013. Available online: https://www.government.nl/documents/reports/2013/10/04/ opportunities-for-a-circular-economy-in-the-netherlands (accessed on 14 December 2017).

59. D'Amato, D.; Droste, N.; Allen, B.; Kettunen, M.; Toppinen, A. Green, circular, bio economy: A comparative analysis of sustainability avenues. J. Clean. Prod. 2017, 168, 716-734. [CrossRef]

60. Geissdoerfer, M.; Savaget, P.; Bocken, N.M.P.; Hultink, E.J. The Circular Economy-A new sustainability paradigm? J. Clean. Prod. 2017, 143, 757-768. [CrossRef]

61. Martins, N.O. The Classical Circular Economy, Sraffian Ecological Economics and the Capabilities Approach. Ecol. Econ. 2018, 145, 38-45. [CrossRef]

62. Veleva, V.; Bodkin, G. Corporate-entrepreneur collaborations to advance a circular economy. J. Clean. Prod. 2018, 188, 20-37. [CrossRef]

63. Urbinati, A.; Chiaroni, D.; Chiesa, V. Towards a new taxonomy of circular economy business models. J. Clean. Prod. 2017, 168, 487-498. [CrossRef]

64. Franco, M.A. Circular economy at the micro level: A dynamic view of incumbents' struggles and challenges in the textile industry. J. Clean. Prod. 2017, 168, 833-845. [CrossRef]

65. D'Amato, G.; Vitale, C.; Rosario, N.; Neto, H.J.C.; Chong-Silva, D.C.; Mendonça, F.; Perini, J.; Landgraf, L.; Solé, D.; Sánchez-Borges, M.; et al. Climate change, allergy and asthma, and the role of tropical forests. World Allerg. Org. J. 2017, 10, 11. [CrossRef] [PubMed]

66. Stihijnye Bedstviya i Tekhnogennye Katastrofy: Preventivnye Mery; Al'pina Pablisher: Moscow, Russian, 2011; p. 312. ISBN 978-5-9614-1527-8.

67. Toma, P.; Massari, S.; Miglietta, P.P. Natural resource use efficiency and economic productivity. In Life Cycle Approaches to Sustainable Regional Development; Massari, S., Sonnemann, G., Balkau, F., Eds.; Routledge-Taylor and Francis Group: London, UK, 2017; Chapter 21; pp. 143-148.

68. EuromonitorPassportDatabase. Available online: http://www.euromonitor.com/ (accessed on 15 May 2018).

69. WorldBankOpenData. Available online: http:/ / data.worldbank.org/ (accessed on 15 May 2018).

70. Mcgarvey, B.; Hannon, B. Dynamic Modeling for Business Management: An Introduction; Springer: New York, NY, USA, 2004; p. 258. ISBN 978-0-387-21556-3.

71. De Leo, F.; Miglietta, P.P. The contribution of environmental indicators to the sustainable performance of countries. Int. J. Sustain. Policy Prac. 2015, 11, 12-26. [CrossRef] 